\section{Customer Knowledge Management (CKM): Model \\ Proposal and Evaluation in a Large Brazilian Higher Education Private Group}

\author{
Alessandro Henrique de Souza Miake ${ }^{\dagger}$ \\ UNIPAC - Faculdade Única de Ipatinga \\ Rodrigo Baroni de Carvalho ${ }^{\Omega}$ \\ Pontifícia Universidade Católica de Minas Gerais \\ Marcelo de Rezende Pinto ${ }^{*}$ \\ Pontifícia Universidade Católica de Minas Gerais \\ Alexandre Reis Graeml * \\ Universidade Tecnológica Federal do Paraná
}

\section{ABSTRACT}

The CRM process is supported by the relationship orientation and the customer knowledge management derived from data collection, data consolidation, data analysis and knowledge distribution to support decision making. The interaction between CRM and Knowledge Management (KM) is quite intuitive, especially when both are supported by Information Technology. The goal of this paper is to develop a Customer Knowledge Management (CKM) theoretical model in order to assess its contribution to the relationship management of students at one of the largest higher education private groups of the world. A state of contrasts comparing groups of students exposed to CKM-designed marketing campaigns (approximately 600,000 students) and unexposed ones (approximately 17,000 students) demonstrated how the proposed model effectively contributed to CRM initiatives. It was found that students exposed to marketing activities had a higher reenrollment rate than those that were not reached by the campaign. It was also possible to calculate the return on investment (ROI) of CKM activities.

Keywords: Customer relationship management (CRM); Knowledge management; Customer knowledge management (CKM); Higher education.

\section{INTRODUCTION}

Customer relationship orientation has been increasingly solidified as a research field and an organizational practice (PARVATIYAR; SHETH 2000), gaining visibility in its opposition to the customer transaction oriented perspective. The fusion of this market orientation and Information Technology (IT) usage has given rise to CRM (Customer Relationship Management) (GEBERT; GEIB; KOLBE; BRENNER, 2003).

It is noteworthy that CRM is not just a technology, but also a managerial approach that demands a review of corporate mission, values and objectives (BAMBRILLA et al., 2007). This discipline in
Corresponding author:

† UNIPAC - Faculdade Única de Ipatinga

E-mail:miakebh@hotmail.com

$\Omega$ Pontifícia Universidade Católica de Minas Gerais

E-mail: baroni@pucminas.br

¥ Pontifícia Universidade Católica de Minas Gerais

E-mail:marcrez@hotmail.com

* Universidade Tecnológica Federal do Paraná

E-mail: graeml@utfpr.edu.br

Received: 08/22/2016.

Revised: 09/26/2016.

Accepted: 11/17/2016.

Published Online: 12/01/2017.

DOI: http://dx.doi.org/10.15728/bbr.2018.15.2.3 
managing knowledge, involving customer relationship, has been largely practiced in many industries, such as retail, banking and telecommunication. A recent study from the Gartner Group (2015) unveiled that US\$20.4 billion and US\$23.4 billion were the values for the revenues of CRM tools market for the years of 2013 (13.7\% growth over 2012) and 2014 (14.7\% growth over 2013), respectively.

The CRM process is supported by the relationship orientation and the customer knowledge management derived from data collection, data consolidation, data analysis and knowledge distribution to support decision making. Gebert et al. (2003) observed that CRM and Knowledge Management (KM) possess a considerable synergic potential, because KM acts as a service provider to CRM initiatives. The need for managing customer knowledge makes CRM and KM interaction quite intuitive (FERREIRA; SANTOS, 2007; MORENO; MELÉNDEZ, 2011; SEDIGHI; MOKFI; GOLRIZGASHTI,. 2012). Nevertheless, besides such intuitiveness, studies connecting both subjects are still scarce in the literature with praiseworthy exemptions to Gebert et al. (2003), Ferreira and Santos (2007), Lopes-Nicolas and Molina-Castillo (2008), Moreno and Meléndez (2011), Talet (2012), Sedighi et al. (2012) and Khodakarami and Chan (2014).

More recently, interdisciplinary works about the interplay of CRM and KM has resulted in a new concept, of CKM (Customer Knowledge Management). CKM is characterized by the acquisition, development, sharing and maintenance of customer knowledge in order to maximize its value (SEDIGHI et al., 2012). The main objective of CKM is to increase customers' satisfaction (TALET, 2012) by appropriate management of existing knowledge about their needs and preferences.

In the Brazilian context, the private higher education sector has been characterized by fast growing and an intense merge and acquisition (M\&A) movement, instigating competition among large players (MAINARDES et al., 2012). According to INEP - the Brazilian National Institute of Educational Studies and Researches, the number of private higher education institutions more than tripled in seventeen years, growing from 684 schools in 1995 to more than two thousand institutions in 2013 (INEP, 2014).

In the higher education market, managing knowledge about students is an essential resource to support relationship management, especially in minimizing churning (students who quit before the end of the course). The new context for higher education institutions has 4D dimensions: Dynamic; Difficult due to the international crisis; Diverse on account of different strategies for different markets; and Delicate since students are more demanding (IORDACHE-PLATIS, 2010). In spite of the concept of customer in higher education being similar to that in other markets, it is worthy to emphasize that students are consumers of a very particular type of service, making them individuals who are being formally educated and who behave differently from other types of services consumers. Henceforth, the objective of this paper is to propose a CKM (Customer Knowledge Management) model in order to assess its contribution to the relationship management of students at one of the largest higher education private groups of the world.

The paper is structured as follows. Section 2 encompasses the theoretical background with three pillars: practices, phases and types of CRM and also customer knowledge categories; knowledge conversion modes and KM software applied within CRM context; and synergies between CRM and KM. Section 3 emphasizes the development of an integrated CKM model. Section 4 outlines the research methodology and section 5 presents the descriptive and quantitative analysis of the CKM model application. Section 6 discusses the major implications of the study, showing its limitations and proposing further works. 


\subsection{RELATIONSHIP MARKETING AND CRM}

Parvatiyar and Sheth (2000) stated that CRM and relationship marketing are terms that are frequently used in an indistinctive manner in the marketing literature. Actually, they are highly correlated themes, since CRM can be seen as the systematic and automatized application of relationship marketing concepts. However, the origin of such concepts has occurred in different times, since relationship marketing has appeared before CRM. According to Gebert et al. (2003), CRM was derived from the combination of a new approach to manage customers with an information systems (IS) orientation, particularly with technologies for transaction management and sales forces automation.

CRM is a customer oriented model where an individual sale is just the beginning of a process, opposing to the product oriented view, where the sale is the end of the process (RYGIELSKI; WANG; YEN, 2002; LIN; SU; CHIEN, 2006). In the CRM perspective, organizations seek to maximize customers' value by analyzing their lifecycle and exploiting business analytics and relationship management technologies (RYGIELSKI et al., 2002; SEDIGHI et al., 2012). The intensive usage of customer information is quintessential to the correct and efficient relationship management (BRETZKE, 2001), emphasizing the strategic contribution of information and knowledge management to CRM initiatives.

In our study, five different classifications were found to typify CRM: operational CRM, analytical CRM, collaborative CRM, strategic CRM and electronic CRM (Table 1).

Majorly, CRM types are grouped in three categories which will be further considered in our CKM model development:

- Operational CRM: its main function is to automatize the CRM process, increasing efficiency and productivity. Customer care and support units, call centers, sales force systems and business rules automation belong to this category;

- Analytical CRM: concerns the CRM intelligence and is related to the analysis and management of customer knowledge. This intelligence layer requires predictive modelling of customer behavior and understanding of sales patterns. Data Warehouse (DW), Data Mining and Online Analytical Processing (OLAP) tools are examples of the technologies that support this category;

- Collaborative CRM: its main purpose is to manage, integrate and synchronize the communication channels and contact points between the customer and the firm. Social networks, e-mails, websites and portals are examples of platforms in which collaborative CRM can be applied.

Table 1. CRM types found in literature.

\begin{tabular}{|c|c|c|c|c|c|}
\hline \multirow{2}{*}{ References } & \multicolumn{5}{|c|}{ CRM Types } \\
\hline & Operational & Analytical & Collaborative & Strategic & Electronic \\
\hline Schwede (2000) & $\mathrm{X}$ & $\mathrm{X}$ & $\mathrm{X}$ & & \\
\hline Peppers and Rogers (2001) & $\mathrm{X}$ & $\mathrm{X}$ & $\mathrm{X}$ & & \\
\hline Bose and Sugumaram (2003) & $\mathrm{X}$ & $\mathrm{X}$ & & & \\
\hline Henning et al. (2003) & $\mathrm{X}$ & $\mathrm{X}$ & $\mathrm{X}$ & & \\
\hline $\mathrm{Xu}$ and Walton (2005) & $\mathrm{X}$ & $\mathrm{X}$ & $\mathrm{X}$ & & $\mathrm{X}$ \\
\hline Geib et al. (2006) & $\mathrm{X}$ & $\mathrm{X}$ & $\mathrm{X}$ & & \\
\hline Iriana and Buttle (2007) & $\mathrm{X}$ & $\mathrm{X}$ & & $\mathrm{X}$ & \\
\hline Richards and Jones (2008) & $\mathrm{X}$ & & & $\mathrm{X}$ & \\
\hline Ngai et al. (2009) & $\mathrm{X}$ & $\mathrm{X}$ & & & \\
\hline Khodakarami and Chan (2014) & $\mathrm{X}$ & $\mathrm{X}$ & $\mathrm{X}$ & & \\
\hline
\end{tabular}


Customer knowledge is a constituent part of CRM, despite the scarcity of this discussion in the Information System literature (KHODAKARAMI; CHAN, 2014). Table 2 summarizes how some scholars have classified customer knowledge in three categories, depending on the origin and the purpose of the managed knowledge.

Indeed, CRM processes are knowledge oriented processes, because the three types of knowledge (about, from and to the customer) are part of a firm's intellectual capital (GEBERT et al., 2003). The usage of those types of customer knowledge in the knowledge creation process, and the adoption of KM tools to support it, are discussed in the next section.

\subsection{KNOWLEDGE MANAGEMENT (KM)}

There are many definitions of KM because different perspectives of what knowledge is may bring different perceptions about KM (ALAVI; LEIDNER, 2001). For the purposes of this work, KM is understood as a set of methods to generate, organize and share knowledge (DAVENPORT; PRUSAK, 1998). Knowledge creation reflects the firm's capacity to generate, disseminate and internalize new knowledge (NONAKA; TAKEUCHI; 1997). The epistemological dimension distinguishes tacit from explicit knowledge. Tacit knowledge is usually personal, corporal, hard to transfer and embedded into individual cognitive connections. On the other hand, explicit knowledge can be transferred by formal and systematized language, assuming material forms such as in documents, databases and images (NONAKA; TAKEUCHI, 1997).

Knowledge creation occurs by the dynamic interaction of tacit and explicit knowledge represented in a knowledge spiral (NONAKA; TAKEUCHI; 1997). Four types of knowledge conversion emerge in this cycle, which can be exemplified in the CRM context as follows:

- Socialization: comprises the sharing of personal experiences, such as interactions among call center employees, salespersons and customers. Empowered by CRM, these professionals possess knowledge about the product portfolio and customer profiles, offering a more customized attendance and experience. Furthermore, part of the tacit knowledge derived from interacting with customers (e.g. claims, quality issues that differentiate products and services) may also contribute to the customer knowledge base;

- Externalization: occurs within the mapping of manual and tacit processes and business rules, allowing their codification into workflows. Externalization also happens when knowledge about customers is captured from CRM collaborative channels;

- Combination: arrangements of different types of explicit knowledge bring new insights about customers. The analytical CRM supports knowledge combination by accessing data repositories, data mining tools and decision support systems (DSS);

Table 2. Customer knowledge categories.

\begin{tabular}{|c|c|c|c|}
\hline $\begin{array}{l}\text { Knowledge } \\
\text { Category }\end{array}$ & Source & Purpose & Example \\
\hline $\begin{array}{l}\text { About the } \\
\text { Customer }\end{array}$ & $\begin{array}{c}\text { Customer transactions and customer } \\
\text { database }\end{array}$ & $\begin{array}{l}\text { Used to understand customer } \\
\text { motivation towards a personalized } \\
\text { relationship }\end{array}$ & $\begin{array}{l}\text { Demographical and register data, } \\
\text { payment history, characteristics of } \\
\text { the purchased goods and services }\end{array}$ \\
\hline $\begin{array}{l}\text { From the } \\
\text { Customer }\end{array}$ & Customer relationship & $\begin{array}{l}\text { Used to provide enhancements in } \\
\text { products, services and processes }\end{array}$ & $\begin{array}{l}\text { Claims, praises, suggestions, } \\
\text { opinions about products and } \\
\text { services and perceptions about } \\
\text { competitors }\end{array}$ \\
\hline To the Customer & Firm & $\begin{array}{l}\text { Used to comply with customer } \\
\text { request for knowledge related to } \\
\text { products and services supplied by } \\
\text { the firm }\end{array}$ & $\begin{array}{l}\text { Information about products and } \\
\text { services, alerts about deals and } \\
\text { payment dates }\end{array}$ \\
\hline
\end{tabular}

Source: Developed by the authors based upon Garcia-Murillo and Annabi (2002); Park and Kim (2003); Smith and Mckeen (2005); Geib et al. (2006). 
BBR

15,2

- Internalization: comprises the organization learning derived from the study, analysis and interpretation of the existing customer explicit knowledge. The analytical CRM provides OLAP tools and report generators that allow decision makers to explore data and gain new knowledge about customers. This process happens with customers as well, since they also learn from the interactions with the firm's collaborative channels.

Carvalho (2001) classified KM software into eight categories according to their technical features and usage. For the purpose of this paper, the following five suitable tools to customer KM were considered: (i) intranets; (ii) groupware; (iii) workflow; (iv) CBR (Case-Based Reasoning) systems; and (v) Business Intelligence (BI).

\subsection{SYNERGIES BETWEEN CRM AND KM TOWARDS CKM}

Knowing customers is indispensable for a customized relationship, which is a CRM basic premise. The application of KM tools and techniques is essential to capture, store, analyze and allow an organization and its customers to exchange knowledge (LOPEZNICOLAS; MOLINA-CASTILLO, 2008), deeply correlating CRM and KM.

Aware of such possibilities, organizations tend to pursue the integration of CRM and KM processes. KM plays a substantial role in a successful CRM strategy (SALOMANN; DOUS; KOLBE; BRENNER. 2005), since the CRM process is complex and deals with semi-structured or even unstructured knowledge.

The alignment of CRM and KM results in a hybrid perspective (CKM), which is centered on the management of knowledge about, from and to the customers. Salomann et al. (2005) define CKM as the systematization and management of knowledge obtained from the diverse points of interaction with customers. CKM may also be understood as the result of CRM and KM integration because CKM's role is to manage the gathering, codification and dissemination of relevant customer knowledge (KOLBE; GEIB, 2005) in order to assure an effective customer management, promoting enduring customer relationships (LIN et al., 2006). Indeed, the application of CKM results in a win-win relationship. By better knowing their customers, organizations may promote lasting relationships. On the other hand, customers benefits from personalized interactions, particular deals and customized products and services.

\section{MODEL PROPOSITION: CUSTOMER KNOWLEDGE MANAGEMENT}

As previously stated, the amount of studies that connect CRM and KM is small. In our literature review, only two papers presenting a CKM model proposal were found. Gebert et al. (2003) developed a model that considers KM as a service provider to CRM, while Sedighi et al. (2012) designed a model connecting the three types of CRM (operational, analytical and collaborative) to customer knowledge sources and also to knowledge retention, transfer, application and creation processes.

Nevertheless, none of these models presents explicitly the connections between CRM types and knowledge conversion processes. This paper intends to broaden the theoretical understanding of theses interfaces by developing a CKM model that embraces these three dimensions (Table 3).

Based upon these relationships (Table 3), a CKM model was structured, evidencing the interfaces between CRM types, the knowledge spiral and KM software (Fig. 1). The model is a graphic representation of the whole process of CKM, including customer data capture, information organization and storage, information analysis to seek knowledge about the customer, generation of knowledge to the customer for use in marketing campaigns and relationship actions and interaction monitoring to capture knowledge from the customer. 
Table 3. Schema of the relationships between the knowledge spiral, CRM types and KM software.

\begin{tabular}{|c|c|c|c|}
\hline $\begin{array}{l}\text { Knowledge } \\
\text { Conversion } \\
\text { Process }\end{array}$ & CRM Type & KM Software & Description \\
\hline \multirow{2}{*}{ Socialization } & Collaborative & Intranet/Web & $\begin{array}{l}\text { Virtual meeting tools (chats and conference rooms) facilitate } \\
\text { experience exchange among employees and also between the } \\
\text { organization and its customers }\end{array}$ \\
\hline & Operational & CBR & $\begin{array}{l}\text { Call center systems ease the interaction between operators and } \\
\text { customers since real time information (about and to customers) } \\
\text { is available }\end{array}$ \\
\hline \multirow{3}{*}{ Externalization } & Collaborative & Intranet/Web and Groupware & $\begin{array}{l}\text { Knowledge about and from customers is captured by websites, } \\
\text { interactive marketing (e-mail marketing and cellphone messages) } \\
\text { and social networks }\end{array}$ \\
\hline & \multirow[t]{2}{*}{ Operational } & CBR & $\begin{array}{l}\text { Information about and from customers is obtained from } \\
\text { customers' and operators' interactions registered in call center } \\
\text { systems }\end{array}$ \\
\hline & & Workflow & Automation of business rules and processes \\
\hline \multirow{2}{*}{ Combination } & \multirow{2}{*}{ Analytical } & BI & $\begin{array}{l}\text { Organization and storage of customer information in large data } \\
\text { repositories (data warehouse and database management systems) }\end{array}$ \\
\hline & & & $\begin{array}{l}\text { Exploration and analysis of hidden patterns, generating } \\
\text { knowledge about customers (data mining and OLAP) }\end{array}$ \\
\hline \multirow[t]{2}{*}{ Internalization } & Collaborative & Intranet/Web and Groupware & $\begin{array}{l}\text { Customers may learn about products and services by absorbing } \\
\text { knowledge produced for the customers. Websites, blogs, } \\
\text { communities, social networks and e-mail marketing may support } \\
\text { this process }\end{array}$ \\
\hline & Analytical & BI & $\begin{array}{l}\text { Decision makers obtain knowledge about customers by using } \\
\text { reports generated by analytical tools }\end{array}$ \\
\hline
\end{tabular}

Source: Elaborated by the authors.

Indeed, the CKM process is interactive and also iterative. It is interactive because it is based on the relationship with the customer, regardless of the channel of communication being used. It is iterative since the repetition of each transaction is an opportunity to gain more customer knowledge.

The data warehousing processing starts with capturing and integrating relevant data to business needs. Besides data sources about, to and from the customer, data sources concerning the competition, economic and financial indexes, demographics, suppliers and partners are also important to relationship management. These diverse and multifaceted data are then filtered, organized and stored in a single data warehouse.

Subsequently, these data will be analyzed by data mining tools, seeking for patterns and relevant associations, and also by decision support systems, to help managers dealing with unstructured problems. In this step, the analytical intelligence feature of the proposed CKM model is activated to process knowledge about and from the customer, generating new knowledge to support customer relationships. The CKM process described so far integrates the Analytical CRM and involves BI systems to support the combination of existing knowledge and the generation of new knowledge.

The next step, the operational CRM, is supported by workflow and CRM systems. Workflow helps externalizing knowledge by means of processes and business rules, which are tacitly instilled in individuals. It is a critical step in the deployment of the CKM model. Externalization relies on documents such as process maps and flow charts, allowing for the automation of rules and decision routes, in a more structured approach to the design of marketing campaigns and relationship actions, minimizing manual work and reducing the chance of mistakes.

Case-Based Reasoning (CBR) systems support call center operators and personal attendants with information about and to customers, enhancing socialization connections. Additionally, CBR systems allow knowledge externalization to take place because 

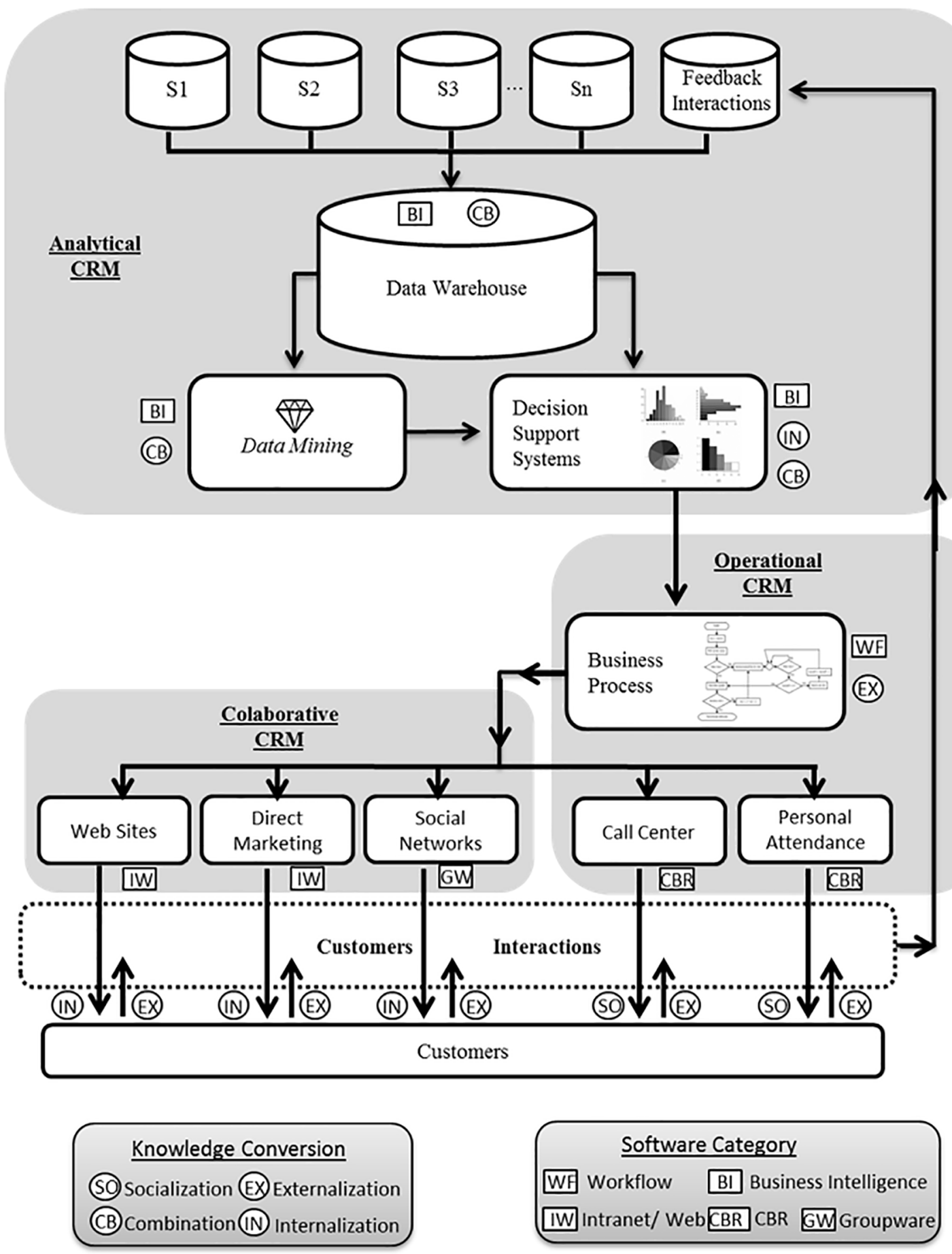

Source: Elaborated by the authors.

Figure 1. Customer Knowledge Management (CKM) model.

information from customers that was fed into knowledge bases, based on feedback interactions, is analyzed by the analytical CRM.

In its turn, the collaborative CRM represented in the CKM model (Fig. 1) comprises web portals, social networks and direct marketing channels (e-mail marketing and cellphone messaging). These particular channels make explicit knowledge available to customers (externalization) and also capture explicit knowledge from customers (internalization) by learning from the relationship interactions between the parts. 
It is important to emphasize that the proposed CKM model intends to be generic and requires accommodation to each specific organizational context. The adoption of CKM relies on a comprehensive managerial and technological analysis of each specific situation. Considering CKM only as an IT-based project may yield limitations on its benefits or even lead to project failure (RIGBY; REICHHELD; SCHEFTER, 2002).

\section{RESEARCH METHODOLOGY}

After investigating CRM and KM literature and developing the CKM model, the next research steps were deploying CKM in a Brazilian private higher education institution and assessing the effectiveness of the marketing efforts that resulted from the new CKM model.

In this context, the assessment involved understanding the model's usage contribution to marketing results in the studied organization. In the education institution, relationship marketing actions with students were developed inspired by the CKM model. These marketing actions were interactions with students based on the analysis of knowledge about and from students in order to generate knowledge to students. These interactions took place in personal and direct attendance to students, direct marketing (SMS and e-mail), social networks (the institution's Facebook fan page) and interactions through the call center.

For the purpose of this work, a quantitative research strategy was adopted to measure the results of applying the proposed model as a support to student relationship management. The choice of adopting an experimental method is related to the explicative intentions (GREENWOOD, 1973) related to the objective of this research, since we would like to determine the cause-effect relationship concerning the use of CKM and the effectiveness of marketing campaign results. The type of experiment that was carried out was field experiment, examining an intervention in the real world (GREENWOOD, 1973).

The following stages were followed during the development of the research experiment (Fig. 2): (i) Selection of an eligible group for a specific relationship marketing campaign; (ii) Separation of case group and control group by using simple random sampling (SRS), assuring group proportionality; (iii) Exposition of the independent (effect) variable which was the marketing campaign designed and managed by the proposed CKM model; (iv) Measurement of the variation on dependent variables (enrollment and reenrollment indexes); (v) Performance of significance tests on the achieved differences by means of the chi-square $\chi^{2}$ test, used to verify the actual dependence of the dependent variable on the independent variable (SOARES; SIQUEIRA, 2002).

\section{RESULTS AND DISCUSSION}

\subsection{EMPIRICAL UNIT OF ANALYSIS}

The research's unit of analysis was a Brazilian private high education group that holds several institutions and brands providing face-to-face and distance learning services. The institution is present in all states (twenty seven) of Brazil and is currently the leader in the Brazilian higher education market, with more than seven hundred thousand $(700,000)$ students attending more than 70 programs in 450 distance learning facilities and 50 faceto-face learning campi (data from 2014). The group is an open market organization and its stocks are traded at the São Paulo stock exchange (BM\&F BOVESPA) since 2007 (BOVESPA, 2014).

The educational group is structured with nine vice presidencies (VP), one of which is in charge of marketing and sales. The customer retention and loyalty area, with is responsible for the CRM and also the DBM (database marketing) activities responds to this vice presidency. This area designs the student marketing campaigns in order to 


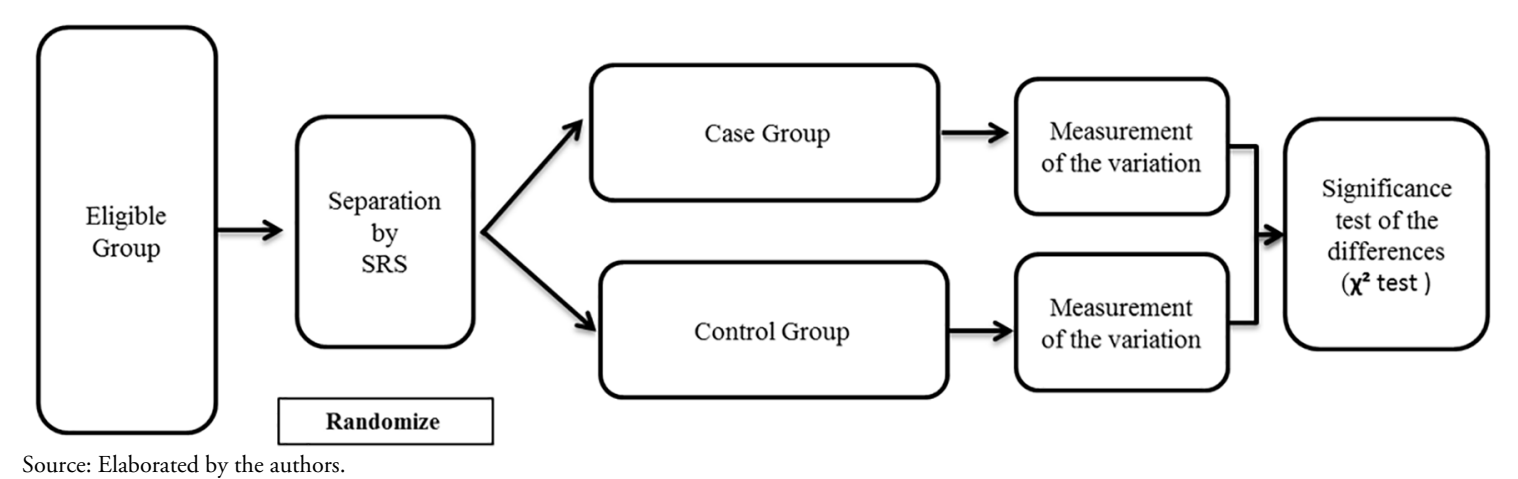

Figure 2. Field experiment stages to compare frequency distribution between random groups.

increase reenrollment every semester. This team is also responsible for the deployment and management of CKM initiatives. One of the authors of this paper was the leader of that team at the time the theoretical model was built, which provided us with a good practical situation to develop the field experiment.

\subsection{DESCRIPTIVE ANALYSIS OF THE CKM MODEL APPLICATION}

The CKM model (Fig. 1) was deployed at the first time in the educational institution from December 2013 to September 2014. The model guided the control of all student reenrollment campaigns and the actions addressed to ex-students (term used to describe inactive students who evaded during previous semesters). The following steps were taken to deploy the CKM model.

The first step (Analytical CRM phase) was the mapping and integration of diverse data sources. This step occurred from December 2013 to February 2014 and involved the mapping of financial, demographic and registration data from students. Most of the data sources were dispersed across many departments in "information islands". It was possible to identify excessive and sometimes unappropriated marketing approaches to students, resulting in dissatisfaction, due to redundant contacts. Data were captured, organized and integrated into a single data repository, called student retention database. Business Intelligence (BI) back-end tools were used to support the ETL (extraction, transformation and load) process.

Still in the Analytical CRM phase, a data mining process was conducted from February to May 2014 to discover relevant knowledge about the students. Based on the analysis of the retention database, it was possible to identify patterns concerning the academic and financial engagement of students, i.e., measurements of how dedicated the students were to their academic life and the financial responsibilities associated to the continuity of their studies. Such information was made available through BI analytical portals to the retention and loyalty area, in charge of the marketing actions of the educational institution. The BI analytical portals were used to support the combination of the knowledge generated by data mining and the knowledge internalization by the marketing team.

The marketing strategy was based on the segmentation of offerings, channels, frequency and content of the messages directed to students and ex-students according to their profile. Despite the scarcity of studies concerning the development and usage of segmentation in higher education marketing, segmentation has already proven to be a fundamental tool for marketing strategy, especially in the service sector (JIMÉNEZ-CASTILLO; SÁNCHEZFERNANDEZ; INIESTA-BONILLO, 2013). The segmentation based upon the learning modality is justified by the differences of the academic model, business model and student profile between face-to-face program, distance program 1 and distance program 2, which are different brands of the higher education group. Concerning the student type, segmentation 
is also necessary since different target publics will receive specific offers. Moreover, for each segment, the educational group uses specific managerial indicators.

The next step (Operational CRM phase) comprised the construction of student relationship rules, defining workflows to organize student relationship actions in a sequential and conditional manner. This approach is sequential because it distributes relationship actions across a predetermined period of time, detailing the clock for marketing actions. It is also conditional, because it has decision points that are influenced by the financial and academic engagement of the student and the student's response to each previous interaction.

Next, marketing actions were performed involving the students and ex-students through diverse communication channels, selected by the previously mentioned workflows. Call center and face-to-face interactions were used in these actions, supported by CBR (which are part of Operational CRM), and also web portals, social networks and direct marketing (SMS, e-mail, direct mail), which are part of Collaborative CRM.

The interactions happened in a consecutive manner according to the student profile and his/her responses to each interaction. There were variations in the content, in the frequency and in the communication channels that were used to interact with students. All interactions were registered and their results (knowledge from students) were included again in the student retention database, so they could, once more, be analyzed to determine the next type of interaction with the student.

Marketing actions were performed according to the type of the program (face-to-face or distance learning), the student's status (active or not) and the phase during the reenrollment period, resulting in approximately 130 different marketing actions. The content and style of the messages of the marketing action observed the student profile which compass academic, financial, demographic and enrollment information and also the answer patterns for each marketing interaction.

The number of active students and ex-students exposed to the marketing campaigns was about six hundred thousand individuals. Control groups were randomly extracted from this universe to measure the effectiveness of marketing actions, disregarding students who reenrolled by themselves, without the influence of marketing campaigns. Control groups represented seventeen thousand students, which were not exposed to any type of message from the institution, letting the reenrollment happen in an absolutely spontaneously way. In the quantitative analysis of the proposed CKM model, it was expected that the students of the control group (spontaneous reenrollment) would present a lower reenrollment rate than the students impacted by the CKM based marketing campaigns. The difference between the two rates was considered the business result of the marketing actions.

\subsection{QUANTITATIVE ANALYSIS OF THE CKM MODEL}

The reenrollment indexes for the second term of 2014 were used for the quantitative analysis of the CKM model. The reenrollment process was called reenrollment campaign. It took place from June to September 2014 and comprised the reenrollment in face-to-face and distance learning programs. The index of ex-students, who had evaded in previous terms and came back now, was also measured in a campaign that was called "win back".

A contrast scenario to verify the effectiveness of the marketing campaigns was created for the following two groups: case group (students exposed to marketing campaigns designed by the CKM model) and control group (students not exposed to marketing campaigns). A chi-square test $\left(\chi^{2}\right)$ was used to verify the dependence of the dependent variable on the independent one, as proposed in Soares and Siqueira (2002). The purpose of the test was to check if the rate of enrollments of ex-students (win back) and reenrollment of current students was influenced or not by the marketing actions designed based on the CKM model. The hypotheses verified by the test were if the rate of enrollments of ex-students (win 
back) and reenrollment of current students is positively influenced by the marketing actions designed based on the CKM model or not.

Next, the test results will be presented separately for different programs (face-to-face program, distance learning brand 1 and distance learning brand 2) and depending on the student profile (current student exposed to reenrollment campaign or ex-student exposed to "win back" campaign), resulting in six combinations (Tables 4, 5 and 6). This separation is necessary not only because of the fact that the program could affect the effectiveness of the campaign (distance learning students are somewhat different to face-to-face students and the business models used for each of those businesses are also distinct), but also because of the differences between current students and ex-students.

The marketing campaigns were not significant to the enrollment (win back) of exstudents (Tables 4, 5 and 6). This result was further confirmed by the chi-square dependency verification (Table 7). For p-values greater than 0.05, is not rejected (Table 7), i.e., the verified rates for the case group and the control group are not statistically different. On the other hand, the marketing campaigns have made significant differences on the reenrollment indexes of current students. For this group, p-values were lower than 0.05 , resulting in the rejection of , i.e., showing that the marketing campaign was important to keep students loyal.

The marketing campaign directed to ex-students has not obtained the same success of the campaign targeted to current students, reinforcing the importance of CKM for better understanding of relationship patterns. For the current students, it was possible to monitor the academic routine, the monthly payments and the satisfaction with the services and use updated demographic and register data. In the counterpart, for ex-students, the campaign design were based only demographic and register data. The richness and variety of data concerning the current students have leveraged marketing results, since the campaigns have exploited the existing customer knowledge.

Table 4. Results of enrollment and reenrollment for face-to-face programs.

\begin{tabular}{ccccccc}
\hline & \multicolumn{3}{c}{ Face-to-face - Ex-Students } & \multicolumn{2}{c}{ Face-to-face- Current Students } \\
\cline { 2 - 7 } & Potential Public & $\begin{array}{c}\text { Number of } \\
\text { Enrollments }\end{array}$ & \% Enrollment & Potential Public & $\begin{array}{c}\text { Number of } \\
\text { Reenrollments }\end{array}$ & \% Reenrollment \\
\hline Case group & 54,206 & 8,388 & $15.47 \%$ & 179,152 & 148,226 & $82.74 \%$ \\
Control group & 2,235 & 373 & $16.69 \%$ & 1,844 & 1,279 & $69.36 \%$ \\
\hline
\end{tabular}

Source: research data.

Table 5. Results of enrollment and reenrollment for distance program 1 (DP1).

\begin{tabular}{ccccccc}
\hline & \multicolumn{3}{c}{ DP 1 - Ex-Students } & \multicolumn{3}{c}{ DP 1 - Current Students } \\
\cline { 2 - 7 } & Potential Public & $\begin{array}{c}\text { Number of } \\
\text { Enrollments }\end{array}$ & \% Enrollment & Potential Public & $\begin{array}{c}\text { Number of } \\
\text { Reenrollments }\end{array}$ & \% Reenrollment \\
\hline Case group & 83,781 & 7,043 & $8.41 \%$ & 303,781 & 257,958 & $84.92 \%$ \\
Control group & 2,936 & 242 & $8.24 \%$ & 6,000 & 4,671 & $77.85 \%$ \\
\hline Source: research data. & & & & &
\end{tabular}

Table 6. Results of enrollment and reenrollment for distance program 2 (DP2).

\begin{tabular}{ccccccc}
\hline & \multicolumn{3}{c}{ DP 2 - Ex-Students } & \multicolumn{3}{c}{ DP 2 - Current Students } \\
\cline { 2 - 6 } & Potential Public & $\begin{array}{c}\text { Number of } \\
\text { Enrollments }\end{array}$ & \% Enrollment & Potential Public & $\begin{array}{c}\text { Number of } \\
\text { Reenrollments }\end{array}$ & \% Reenrollment \\
\hline Case group & 46,696 & 3,788 & $8.11 \%$ & 75,954 & 57,222 & $75.34 \%$ \\
Control group & 1,923 & 151 & $7.85 \%$ & 2,156 & 1,269 & $58.86 \%$ \\
\hline Source: & & & & &
\end{tabular}


Table 7. Results of $\chi^{2}$ (chi-square) tests to verify dependency.

\begin{tabular}{ccc}
\hline Type of Learning & Student Type & P-value \\
\hline \multirow{2}{*}{ Face-to-face } & Ex-Students & 0.19 \\
& Current Students & $0.00^{*}$ \\
\hline \multirow{2}{*}{ DP 1 } & Ex-Students & 0.77 \\
& Current Students & $0.00^{*}$ \\
\hline \multirow{2}{*}{ DP 2 } & Ex-Students & 0.71 \\
& Current Students & $0.00^{*}$ \\
\hline
\end{tabular}

Note. The symbol * indicates significant differences between proportions.

Source: research data.

It was possible to measure the return on investment (ROI) of the marketing campaigns, since there was an increase in reenrollment among current students. Next, the calculation of the marketing investments and the financial return is explained.

The following items were considered for the estimation of marketing investments: (i) payroll costs (taxes included) of the team involved in developing the marketing campaign (application of the CKM model); (ii) call center cost during the campaign; (iii) personal attendance cost; (iv) direct marketing costs (e-mails and cell phone messages). The financial return of the marketing campaign was calculated based on the increase of reenrollments. The increase was obtained from the difference between the total of reenrollments (case group) and the total of students that would be expected to reenroll if the same reenrollment rate that happened for the control group happened also for the remaining of the potential public (Tables 8, 9 and 10).

After calculating the increase of students for each program, it was possible to multiply this number by the respective average monthly fee paid by students of each program (face-to-face, distance learning programs 1 and 2) for a six month period (six fees for one term). That product was then divided by the marketing investment. There were no additional Information Technology (IT) investments for the CKM initiative, since the technological infrastructure was already available because the institution uses it for other business processes. Due to the secrecy agreement for this research, the absolute values of the marketing investments and the financial return cannot be presented here. However, the following ratio represents the calculated ROI for the marketing actions.

Table 8. Increase in reenrollment resulting from CKM-designed campaign - Face-to-face Education Program.

\begin{tabular}{cccc}
\hline & Face-to-face Education Program - Current Students \\
\hline & Case Group & Control Group & Increase \\
Potential public & 179,152 & 179,152 & 179,152 \\
\% Reenrollment & $82.74 \%$ & $69.36 \%$ & $13.38 \%$ \\
Number of reenrollments & 148,226 & $124,260^{*}$ & 23,966 \\
\hline $\begin{array}{l}\text { Note. The symbol * in this table and in the following ones denotes the number of students estimated to reenroll if no marketing campaign had occurred (based } \\
\text { on what happened with the control group). Source: research data. }\end{array}$
\end{tabular}

Table 9. Increase in reenrollment resulting from CKM-designed campaign - Distance Learning 1.

\begin{tabular}{cccc}
\hline & & Distance Learning Program 2- Current Students & \\
\hline & Case Group & Control Group & Increase \\
Potential public & 75.954 & 75.954 & 75.954 \\
\% Reenrollment & $75.34 \%$ & $58.86 \%$ & $16.48 \%$ \\
Number of reenrollments & 57,222 & $44,706^{*}$ & 12,516 \\
\hline
\end{tabular}


BBR

15,2

147

Table 10. Increase in reenrollment resulting from CKM-designed campaign - Distance Learning 2.

\begin{tabular}{cccc}
\hline & & Distance Learning Program 2 - Current Students & \\
\hline & Case Group & Control Group & Increase \\
Potential public & 75.954 & 75.954 & 75.954 \\
\% Reenrollment & $75.34 \%$ & $58.86 \%$ & $16.48 \%$ \\
Number of reenrollments & 57,222 & $44,706^{*}$ & 12,516 \\
\hline
\end{tabular}

Source: research data.

$R O I=\frac{\text { Financial Return }}{\text { MKT Investment }}$, where:

Return Financial $=$ Increase in Students' Enrollment $\times$ Average Monthly Fee $\times 6$

Marketing Investments $=\sum$ Marketing costs

Even considering that the simplified calculation does not take into account the cost of delivering the educational services (which means that the actual ROI could be a little less), the calculated return is amazingly high: for each US\$ 1 invested in marketing, the expressive ROI of US\$ 148 was obtained.

\section{CONCLUSION}

The main contribution of this paper is the proposed CKM model, which integrates the theoretical interfaces between customer relationship management (CRM), the processes involved in the knowledge spiral and KM tools. The model describes, in a thorough way, all stages of the process, since the acquisition and integration of customer data, going through the processing and analysis of such data, the interactions with customers, and the feedback obtained from those interactions. These stages were organized in an iterative way, creating a process with feedback links that generate continuous learning about, from and to the customers.

Another important contribution of the model refers to its ability to reduce the risks involved in implementing CRM, as KM deals with the little structuration of CRM. On the other hand, CRM helps KM to align to the business processes that focus on the customer.

The proposed model can be used by any other organization, as a guideline to implement or evolve CRM projects, following the same procedures that were described here for the studied higher education institution. For organizations that already have an infrastructure of KM tools, the model becomes even more useful, as it specifies the CRM activities that can be supported by KM tools.

The studied case illustrated the importance of the data warehousing process, comprising the Analytic CRM stage, in which data sources from different areas in the organization were mapped and integrated. The main gains of such unification were the combination of different data sources in the generation of knowledge about customers and the improvement in managing the interactions with them, avoiding excessive or unsuitable approaches, which could generate dissatisfaction due to their redundancy.

Another gain, still, in the process of implementing the model in the studied organization, happened in the Operational CRM stage, more specifically in mapping, documenting and automating processes and business rules. Several processes and business rules were externalized, by means of interviews and meetings with the people that had the knowledge about them, for the creation of process maps and workflows, used in automating such processes and business rules. 
Marketing initiatives, by means of collaborative channels, in addition to conveying relevant information to customers, capture important feedback from them, while they interact with the organization (knowledge from the customers), determining subsequent actions. That feedback became an important data source in the Analytic CRM capture process, feeding the data warehousing.

This paper highlighted the fact that the adoption of CRM to improve knowledge management about, to and from the customer requires not just a suitable technological infrastructure, but mainly a revision of managerial and operational processes of customer management.

Over six hundred thousand students were approached my means of a marketing campaign based on the proposed model, in more than one hundred and thirty distinct marketing initiatives. All those students were classified in six different clusters, according to the student profile (current student or ex-student) and the type of program (Face-to-face program, Distance learning program 1 or Distance learning program 2). The three clusters that involved current students presented statistically significant results after being exposed to the intended marketing initiatives, when compared to those in the control group. On the other hand, the three clusters that involved ex-students, who had given up their studies in previous semesters, did not respond differently, with respect to the marketing campaign, to those in the control group.

Results allow for the important finding that intense use of data, aiming at increasing knowledge about customers and supporting the relationship with them, generates value to the business. When students are approached in a segmented way and with offers that suit their needs, there is an increase in the reenrollment rate. Monitoring the academic routine, payment of monthly fees, the satisfaction with the received services, the interactions with the organization (which contribute to the knowledge from the customer), and dealing with that information together with other demographic and schooling data, enabled the team in charge of the marketing effort to develop a distinctive marketing approach, which took into consideration the profile of each individual student, his/her financial situation and the progress s/he had already made in the program. Iordache-Platis (2010) states that the CRM cycle in a higher education institution comprises five steps: (i) contacting the potential student; (ii) informing the candidate; (iii) convincing the candidate; (iv) providing educational services; (v) feedback. Since this cycle repeats every term, the CKM proposed model could be used to support the second, third and fifth steps.

The institution also developed a marketing campaign for ex-students, trying to win them back, but that was carried out based only on demographic data and previous records on the student that were not so complete. Although such data were important for operational activities, they only allowed for a limited view of the individual, when compared to the "behavioral" data that the institution used in dealing with its current students.

The return on the investment (ROI) of the marketing campaign, which, at the bottom line, represents the financial return on the marketing expenses, represented about 148 times the invested money. This figure shows how amazingly profitable this kind of managerial initiative can be.

However, advanced technological tools and a specialized and multidisciplinary work force are required and the implementation of a similar customer management model could involve severe cost constrains. As costs are high and occur in advance to the expected benefits, it may be difficult to convince the decision makers in an organization about the feasibility of such a sophisticated marketing campaign, in spite of the high return rates that may be achieved, as evidenced here. The high implementation costs may make it difficult to implement this kind of project in small and mid-sized organizations, such as smaller higher education institutions. Research with the intent to develop customer management models 
BBR

15,2

149

that are feasible to smaller scale operations is needed and would be a great contribution to practice, as well as an interesting contribution to academia.

Future work could also involve applying the CKM model proposed here to other large organizations and in different industries, as there are many instances in which business could benefit from interacting more with customers, in order to learn from them and provide personalized services, such as telecom, e-commerce, hoteling, financial institutions and health care, among others.

It should be highlighted that the analysis contrasting the case and the control groups, in which significant differences in ROI were observed, involved the comparison among students that were subjected to a marketing campaign based on the proposed model and students that were not submitted to any marketing effort, at all. In the future, a comparison could also be made among students exposed to relationship marketing and customers exposed to generic marketing campaigns (mass marketing that does not use a more elaborate knowledge of the customers in addressing them), in addition to those not addressed by any marketing campaign.

In order to use analytical tools to compete in the market, organizations need changes in their culture, processes and abilities. Everyone in the organization needs to understand and be convinced by such change and this requires involvement of the top management. It is important that the executive team recognizes the value of the customer management model, really believing on its effectiveness, so that it is adopted as an organizational principle that is essential to the company's success. As a strategic marketing concept, CRM needs to be included in the higher education institutions' marketing objectives which should be well defined, precise, measurable and clear (IORDACHE-PLATIS, 2010). Organizations that do not understand that will not be able to know what the world, and more specifically their customers, is trying to tell them. In times of big data, social CRM and all sort of data flowing through the digital universe, exploring and managing the information that is already available in a company's own data bases, and the information customers are happy to share with it, seems to be the sensible thing for any organization to do. However, many are still not prepared for that. Customers are getting tired of being bombarded by organizations with mass-oriented services presented in an impersonal communication style. In order to know the customers in large scale and still offer them personalized support, information technology plays a great role, becoming the major technological support to relationship marketing. It is a matter of choice: innovate and survive or ignore changes in the environment and fail to cope with the intensifying competition and increasing dynamics of the market place.

\section{REFERENCES}

ALAVI, M., \& LEIDNER, D.E. Review: knowledge management and knowledge management systems: conceptual foundations and research issues. MIS Quarterly, v.25, n.1, p. 107-136,2001.

BAMBRILLA, F. R., SAMPAIO, C. H., PERIN, M. G., \& ESPARTEL, L. B. Indicadores de CRM nas Dimensões Tecnológica e Organizacional: um Estudo de Caso Comparativo da Relação entre Teoria, Empresa Desenvolvedora e Empresa Usuária de CRM. I Encontro de Administração da Informação EnADI. Florianópolis, 2007.

BOSE, R., \& SUGUMARAM, V.Application of KM technology in customer relationship management. KnowledgeandProcess Management, v. 10, p. 3-17, 2003.

BOVESPA. BM\&F BOVESPA- A Nova Bolsa http://www.bmfbovespa.com.br/pt_br/produtos/listados-avista-e-derivativos/renda-variavel/empresas-listadas.htm. Acessado em 10 de setembro de 2014.

BRETZKE, M. Marketing de Relacionamento e Competição em Tempo Real. São Paulo: Atlas, 2001. 
CARVALHO, R. B. Tecnologia da Informação aplicada à Gestão do Conhecimento. Belo Horizonte: ComArte, 2001.

DAVENPORT, T., \& PRUSAK, L. Conhecimento Empresarial. $6^{a}$ ed., Rio de Janeiro: Campus, 1998.

FERREIRA, L. A., \& SANTOS, L. S. Uma Avaliação de Soluções de CRM sob a ótica da Gestão do Conhecimento. I EnADI. Florianópolis, 2007.

GARCIA-MURILLO, M., \& ANNABI, H. Customer knowledge management.Journal Operational Research Society, 53, 875-884, 2002.

GARTNER GROUP.CRM: O mercado mundial cresceu 13,3\% no ano passado. http://stefanini.com/ br/2015/05/crm-mercado-mundial-cresce-133-no-ano-passado/. Acessado em 12 de março de 2015.

GEBERT, H., GEIB, M., KOLBE, L., \& BRENNER, W. Knowledge-enable customer relationship management; integrating customer relationship management and KM concepts. Journal of Knowledge Management, v. 7, p. 107-123, 2003.

GEIB, M., KOLBE, L. M., \& BRENNER, W. CRM collaboration in financial services networks: a multi-case analysis. Journal of Enterprise Management, v. 19, p. 591-607, 2006.

GREENWOOD, E. Métodos principales de investigación social empírica. In: Metodologia de la Investigación Social.Buenos Aires, Paidós, Cap. 6, p. 106-126, 1973.

HENNING, G., GEIB, L. M., KOLBE, W., \& BRENNER, W. Knowledge-enable customer relationship management: integrating customer relationship management and knowledge management concepts. JournalofKnowledge Management, v. 7, p. 107-123, 2003.

INEP Sinopses Estatísticas da Educação Superior- Graduação. http://portal.inep.gov.br/superiorcensosuperior-sinopse. Acessado em 10 de outubro de 2014.

IORDACHE-PLATIS, M. Customer relationship marketing for higher education institutions. In Matei, L. (Ed.); Dinu, T. (Ed.), Regulation and best practices in public and nonprofit marketing, p. 599-605. Bucharest:The Economica Publ. House, 2010.

IRIANA, R., \&BUTTLE, F. Strategic, operational and analytical customer relationship management.Journal of Relationship Marketing, v. 5, p. 23-42, 2007.

JIMÉNEZ-CASTILLO, D.; SÁNCHEZ-FERNANDEZ, R; \& INIESTA-BONILLO, M.A. Segmenting university graduates on the basis of perceived value, image and identification. International Review on Public and Nonprofit Marketing, v. 10, n. 3, p. 235-252, 2013.

KHODAKARAMI, F., \& CHAN, Y. E. Exploring the role of customer relationship management (CRM) systems in customer knowledge creation.Information \& Management,v. 51, p. 27-42, 2014.

KOLBE, L. M.; \& GEIB, M. Mini-Track: Customer Knowledge Management. Proceedings of the Proceedings of the 38th Annual Hawaii International Conference on System Sciences, v. 8, p. 239, 2005.

LIN, Y., SU, H., \& CHIEN, S. A knowledge-enable procedure for customer relationship management. Industrial Marketing Management, v. 35, n. 4, p. 446-456, 2006.

LOPEZ-NICOLAS, C., \& MOLINA-CASTILLO, F. J. Customer Knowledge Management and E-commerce: The role of customer perceived risk.International Journal of Information Management, v. 28, p. 102-103, 2008.

MAINARDES, E. W., ALVES, H., RAPOSO, M., \& DOMINGUES, M. J. C. DE S. Marketing in higher education: A comparative analysis of the Brazil and Portuguese cases. International Review on Public and Nonprofit Marketing, v. 9, n. 1, p. 43-63, 2012.

MORENO, A. G., \& MELÉNDEZ, A. P. Analyzing the impact of KM on CRM success: The mediating effects of organizational factors.International Journal of Information Management, v. 31, p. 437-444, 2011.

NGAI, E. W. T., XIU, L., \& CHAU, D. C. K. Application of data mining techniques in customer relationship management. Expert Systems with Applications, v. 36, p. 2592-2602, 2009.

NONAKA, I., \& TAKEUCHI, H. Criação de Conhecimento na Empresa.Rio de Janeiro: Campus, 1997.

PARK, C. H., \& KIM, Y. G. A framework of dynamic CRM: linking marketing with information strategy. Business Process Management Journal,v. 9, n. 5, p. 652 - 671, 2003.

PARVATIYAR, A., \& SHETH, J. N. "The Domain and Conceptual Foundationsof Relationship Marketing." In J. N. Sheth\& A. Parvatiyar (Eds.), Handbook of RelationshipMarketing, p. 3-38. Thousand Oaks, CA: Sage Publications, 2000.

PEPPERS, D., \& ROGERS, M. Marketing 1 to1.2 ed. São Paulo: Makron Books, 2001.

RICHARDS, K. A., \& JONES, E. Customer relationship management: Finding value drivers. Industrial Marketing Management,v. 37, n. 2, p. 120-130, 2008.

RIGBY, D., REICHHELD, F., \& SCHEFTER, P. Avoid the four perils of CRM. Harvard Business Review, v. 80 , n. 2, p. 101-109, 2002. 
RYGIELSKI, C., WANG, J., \& YEN, D. C. Data Mining techniques for customer relationship management. Technology in Society, v. 24, n. 4, p. 483-502, 2002.

SALOMANN, H., DOUS, M., KOLBE, L., \& BRENNER, W. Rejuvenating Customer Management: How to Make Knowledge For, From and About Customers Work. European Management Journal, v. 23, n. 4, p. 392-403, 2005.

SCHWEDE, S. Vision und wirklichkeit von CRM [Vision and reality of CRM].Information Management \& Consulting, v. 15, n. 1, p. 7-11, 2000.

SEDIGHI, M. M., MOKFI, T., \& GOLRIZGASHTI, S. Proposing a customer knowledge management model for customer value augmentation: A home appliances case study.Database Marketing \& Customer Strategy Management,v. 19, p. 321-347, 2012.

SMITH, H. A., \& MCKEEN, J. D. Developments in practice XVIII- Customer knowledge management: adding value for our customers. Communications of the Association for Information Systems,v. 16, p. 744-755, 2005.

SOARES, J. F., \& SIQUEIRA, A. L. Introdução à Estatística Médica.Belo Horizonte: Coopmed, 2002.

TALET, A. N. KM Process and CRM to manage Customer Knowledge Relationship Management.International Conference on Economics, Business and Marketing Management, v.29, p. 60-67, 2012.

XU, M., \& WALTON, J. Gaining customer knowledge through analytical CRM.Industrial Management + Data Systems,v. 105, n. 7, p. 955-972, 2005. 